\title{
ПHE RELATIONS BETWEEN TRANSYLVANIAN SAXONS AND BALTIC GERMANS DURING THE 1920s
}

\section{Vasile Ciobanu}

Professor, “Lucian Blaga” University of Sibiu, E-mail: vasileciobanu47@yahoo.com

An earlier version of this paper has been presented at the „Interethnische Beziehungen und regionale Identität. Das Baltikum und Siebenbürgen im Vergleich" symposium organized in 1999 by Bundesinstitut für ostdeutsche Kultur und Geschichte Oldenburg Baltische Historische Kommission and Südostdeutsche Historische Kommission. The German version was published in "Jahrbuch des baltischen Deutschtums 2003", Lüneburg 2002, 194-204 and the Romanian version was published by "Studia Universitatis Cibiniensis. Series Historica", I, 2004, 263271.

\begin{abstract}
:
The relationship between the Saxons and the German Balts has been already investigated, but the available archival material, however, allows me to deepen the problem of cultural relations between the two German minorities. This relationship has taken both an institutional and a personal form. The first form involved cooperation between clubs, societies and editors of publications, while the second consisted of direct contact between cultured people. The two kinds of cooperation have created in the 1920s a network of mental relations based on the solidarity of all Germans living abroad. A special contribution in the establishment of these relations was brought forth by the Cultural Office of the Germans in Greater Romania, founded in 1922 in Sibiu by Richard Csaki, and by the "Ostland" magazine, which was also published in Sibiu starting with 1926. Csaki and others worked in the field of cultural policy together with representatives of the German Balts such as Ewal Ammende, Werner Hasselblatt, Axel de Vries or Max von Ravick. This article investigates these bonds as part of the wider frame of German cultural networks operating in-between the Baltic and the Black sea.
\end{abstract}




\begin{abstract}
Rezumat:
Relatiile dintre Germanii Baltici şi Saşi au constituit deja subiectul unor cercetări. Acest articol adânceşte însă analiza asupra relatiilor culturale dintre cele două minorităti. Două aspecte sunt aici analizate: relațiile culturale la nivel institutional (între cluburi, societăti culturale, publicații) şi cele la nivel personal (contacte directe ale elitelor intelectuale). Cooperarea de acest tip a fost facilitată în anii 1920 de solidaritatea germanilor care trăiau în afara granițelor Germaniei. O atentie deosebită este acordată exemplului oferit de relatiile dintre Biroul Cultural al Germanilor din România Mare, fondat în 1922 la Sibiu de către Richard Csaki, şi magazinul "Ostland", care din 1926 a fost de asemenea publicat la Sibiu. Datele furnizate de acest articol contribuie, de asemenea, la largirea cunoştintelor legate de relatiile culturale desfăşure între zona Mării Baltice şi zona Mării Negre în perioada interbelică.
\end{abstract}

Keywords: Saxons, Balts, cooperation, networks, cultural policy

The study of the interwar relations between Transylvanian Saxons and Baltic Germans is not an entirely new scholarly subject. Authors such as Max Hildeberg Boehm and Michael Garleff have already approached this issue $^{1}$, while the interwar relations between the two German groups have aroused the interest of numerous scholars. ${ }^{2}$

Transylvania and the Baltic States, two European regions situated at the opposite periphery of the German colonization in the East, have been united by their common fate and by the connections established between the German inhabitants of the two historical provinces after the First World War. On the basis of the works published with regard to these relations thus far, of the documents from the Cultural League of the Romanian Germans held in the Sibiu archives, of the mass-media of the time and

\footnotetext{
${ }^{1}$ Max Hildebert Boehm, 'Balten und Siebenbürger Sachsen', Jahrbuch des baltischen Deutschtums (1954), 72-75; Michael Garleff, 'Zu den Literaturbeziehungen zwischen Deutschbalten und Siebenbürger Sachsen. Ein Briefwechsel zwischen Otto von Taube und Erwin Wittstock', Zeitschrift für Siebenbürgische Landeskunde, 17 (1994), nr. 1: 53-66; Michael Garleff, ' Baltische Minderheitenvertreter auf den Europäischen Nationalitätenkongressen 1925-1938' Jahrbuch des baltischen Deutschtums, 33 (1986): 117131.

2 Gert von Pistohlkohrs, coord., Baltische Länder (Berlin, 1994); Wilfried Schlau, Die Deutschbalten (München, 1995); Walter König, coord., Siebenbürgen zwischen den beiden Weltkriegen (Köln-Weimar-Wien: Siebenbürgisches Archiv, 28, 1994); Oskar Schuster coord., Epoche der Entscheidungen. Die Siebenbürger Sachsen im 20. Jahrhundert, second edition (Köln-Wien, 1984); Michael Kroner, Ringen um nationale Selbstbehauptung. Die Siebenbürger Sachsen 1876 bis 1940 (Nürnberg, 1998); Konrad Gündisch, Siebenbürgen und die Siebenbürger Sachsen (München, 1998)
} 
especially of the Sibiu magazine Ostland, I try to reconstitute a series of events and facts regarding the connections between the Saxons ad the Baltic Germans in the 1920s. If the connections between the political leaders of the two groupings in their struggle for the rights of minorities have been already dealt with ${ }^{3}$, without the issue being however entirely worked out, very little is still known about the contributions of cultural figures such as Richard Csaki (1886-1943) or about the Cultural League of the Romanian Germans (CLRG) and the 1926 to 1931 series of the Sibiu-based Ostland magazine.

Culture is the main field where the struggle for cultural identity is undertaken and herein the battles for the rights of minorities are always waged. The relations between the Transylvanian and the Baltic Germans have embraced in the 1920s an institutional and a personal shape. The cooperation between associations and societies, magazines' editorial boards and press services are examples of the former, while the bonds between cultural and scientific personalities are examples of the latter form of cooperation. Both types of interactions have been intensely cultivated in the 1920s with the aim of creating a "network of spiritual relations" among the German minorities situated in Central - East Europe with the aim of mutual knowledge. ${ }^{4}$

The CLRG set up in Sibiu in February 1922 has brought an important though little known contribution to reaching this goal. ${ }^{5}$ The idea of such an organization has originated from Csaki in 1919 when it was understood that Greater Romania included about a million Germans coming from three different countries with little awareness of each other. ${ }^{6}$ Consequently, the CLRG envisaged the unification of Romania's Germans around the Saxons. Additionally, its 1922 programme aimed at creating a spiritual bond with Germany and with the other European German minorities. The League, based in Sibiu, has undertaken a fabulous activity until 1931 when it was shut down bankrupt. The model of CLRG has been copied by the Estonian Germans, within their cultural autonomy, and by the Upper Silesia Germans. ${ }^{7}$ In May 1923 Csaki and his wife, the painter Margarete Depner

\footnotetext{
3 Rudolf Michaelsen, Der Europäische Nationalitäten-Kongress 1925-1928: Aufbau, Kriese und Konsolidierung (Peter Lang, Frankfurt/Main: Bern, New York, Nancy, 1984); Sabine Bamberger-Stemmann, Der Europäische Nationalitätenkongress 1925 bis 1938. Nationale Minderheiten zwischen Lobbyistentum und Großmachtinteressen (Marburg, 2000).

4 'Auslanddeutsche untereinander', Ostland, 1 (1926): 46.

${ }^{5}$ Monica Vlaicu, 'Das Kulturamt der Deutschen', Großrumänien, Siebenbürgische Semesterblätter, 7 (1993): 102-110.

${ }^{6}$ Richard Csaki, 'Unser Kulturprogramm', Ostland, 3 (1921): 231-233.

7 'Kulturämter', Ostland, 2 (1927): 255-256.
} 
Csaki (1885-1970), paid a visit to the Baltic states where he presented his cultural organization thus arising the enthusiasm of local leaders such as Werner Hasselblatt (1890-1958) ${ }^{8}$ from Estonia. On the other hand, Csaki has noticed a series of common features between the history and folk art of Saxons and Balts. His observations following this visit to Latvia have been eventually presented in a series of conferences. ${ }^{9}$ The chairman of CLRG has eventually visited all the European German minorities returning to the Baltic states in 1928 and getting to know well the Baltic Sea rim Germans. Following this visit, he has published an article in his magazine Ostland meaningfully entitled The Baltic Germans now: Transylvanian dedication to our friends from Estonia. ${ }^{10}$ The author declared himself "shaken" by the expropriation of the land of 25,000 Estonian Germans, which he deemed the most radical land reform in Europe, and seemed fascinated by their national conscience.

The action plan of CLRG included the education of the people by popular libraries, slide conferences, educational and cultural movies, didactic materials, exhibitions, postgraduate summer courses, conferences, musical and drama shows and publications. A special section hosted German mass-media and had a reading room for the 250 newspapers and magazines received worldwide, a filing cabinet and a press service. There also existed an economic section, a section for professional orientation and a section dealing with the magazines issued by the league. ${ }^{11}$ In all these fields there existed preoccupations for contacts with the Germans living abroad. The study of the working methods of other cultural organizations, the dissemination of their own results, the spreading of various kinds information of abroad and "the strengthening of the self-consciousness of the German people" were all envisaged by the league. ${ }^{12}$

One of the main achievements of CLRG, with beneficial effects on the bonds with Germans living abroad, was the organization of postgraduate summer courses in Sibiu between 1920 and 1930. The idea behind these courses was a pre-war product of the Sibiu-based Modern Library organization that aimed at cultural unification of South-East European

\footnotetext{
8 Arhivele Naționale ale României, Direcția Județeană Sibiu (hereafter ANR.DJS), Liga Culturală a Germanilor din România (hereafter Liga Culturală), file 4/1924, 263. See also Mads Ole Balling, Von Reval bis Bukarest. Statistisch-Biographisches Handbuch der Parlamentarier der deutschen Minderheiten in Ostmittel- und Südosteuropa 1919-1945, vol. I (Kopenhagen), 124-125.

${ }^{9}$ ANR.DJS, Liga Culturala, file 2/1923, 1131-1132.

10 Ostland, 3 (1928): 33.

11 See Tätigkeitsbericht 1922-1927, Hermannstadt, 1927.

12 Ibid. 49.
} 
Germans. ${ }^{13}$ According to other sources such courses had already taken place before the Great War in Salzburg and Reichenberg (Czechoslovakia). ${ }^{14}$ The courses organized in Sibiu were attended yearly by Germans from all Romanian provinces and by dozens of Germans from other countries "united in a German lofty atmosphere". The speakers were university professors from Romania, Austria, Switzerland and especially from Germany. Among them, one can find Prof. Dr. H. Phelps from Danzig/Gdansk (1923), Prof. Dr. M. Ebert and Prof. Dr. Fuchs (Königsberg) and a team of Baltic Germans led by Prof. Dr. Ernst Seraphim (Königsberg). ${ }^{15}$ In 1925 invitations to deliver lectures at the "culturalpolitical weak" organized in Sibiu were sent to the Balts' leaders Axel de Vries (1892-1963), Ewald Ammende (1893-1936) and Hermann von Berg from Tartu. ${ }^{16}$ In the end, this intention was at first postponed and then never materialized. ${ }^{17}$

Such summer courses have also been organized in the Baltic states, an exchange undertaken between the summer conferences organized by the Herder Society in Riga ${ }^{18}$, the Tartu-held conferences and the Sibiu summer school. Except for the Sudetenland Germans who enjoyed their own university, all the other minorities would attempt to make up for lacking such an institution with these courses which were also serving the purpose of setting up a link with their motherland culture and science. The convener of the courses in Tartu was Dr. R. v. Engelhardt who was of the opinion that they "had to offer a principled basis for the detailed study of the humanistic and natural sciences." 19 The summer courses were attended by $500-700$ participants among whom were also intellectuals belonging to the majority ethnic groups (Romanians, Latvians or Estonians). Thus, the German minorities were also facilitating the access of locals to Western culture and science. As Csaki has underscored the courses were not only disseminating practical competencies, but were also renewing the spiritual bonds with the motherland. "The community of German consciousness" was according to him "the main driving force behind these manifestations". ${ }^{20}$ The CLRG has witnessed the summer courses in

\footnotetext{
13 Ostland, 1 (1919): 107, 201.

14 Ibid., 163; ANR.DJS, Liga Culturală, file. 8, 1926, 525.

15 Siebenbürgisch-Deutsches Tageblatt, 54 (1927), no. 16.253/3 septembrie, 5.

16 See for details O. Balling, 126.

17 ANR.DJS, Liga Culturală, file 5/1925, 4, 584, 592.

18 Ibid., file. 8/1926, 189.

19 Ostland, 1 (1926): 36-40.

20 Richard Csaki, 'Auslanddeutsche Hochschulwochen', Ostland, 2 (1927): 337.
} 
Romania, Latvia, Estonia, Czechoslovakia and Poland and has published in its magazine reports and articles in which the experience of each country was analyzed. ${ }^{21}$

The CLRG has developed contacts, albeit weak as the correspondence recorded in the archives proves, with similar institutions of the Baltic Germans. Thus, in October 1926 Csaki dispatched to the Herder Society in Riga a report about the activity of the Cultural League and requested articles for the magazine Ostland about the achievements of the Latvian organization. Prof. Dr. Paul Sokolowski has preferred instead to send a confidential report. ${ }^{22}$

The Herder Society was set up in Riga in 1921 after the German university there was closed down. A group of professors such as Sokolowski, Kupfer and Klumberg have established an academic institute at university level which was recognized on May 14, 1927 as a private institution, this being the first such institution for minorities in Europe. On the occasion of its fifth anniversary, Csaki wrote that "the most productive achievement of the Baltic Germans after the war, besides the establishment of the cultural autonomy in Estonia, is the setting up of the Herder Institute." 23

The CLRG requested from the Central Office for the Activity of the Baltic Germans in Riga a report about the aims and activity of this organization. In his letter, Csaki expressed his desire to contribute to the strengthening of the relations between the German national communities from Romania and Latvia and invited a representative of the latter to the Cultural-Political Week organized in Sibiu in September 1925. ${ }^{24}$

The organizational chart of the CLRG was also sent to Lithuania where Csaki's activity was known. One of the leaders of the German Party in Lithuania (Partei der Deutchen Litauens), Martin Labrenz wrote that the efforts of the Cultural League constituted a stimulus for the national endeavour of the Lithuanian Germans who were asking for advices for setting up a German library; they also requested German magazines and the addresses of the Romanian German societies. 25

The most important contribution to the relations between the two regions, the Baltic and Transylvania, was brought by the second series of

\footnotetext{
${ }_{21}$ Ibid. 337-343; ANR.DJS, Liga Culturală, file 6/1925, 525, 918; file 8/1926, 188-189; Dr. R. v. Engelhardt, 'Deutsche Bildungsziele im Ostland', Ostland, 1 (1926): 15-23.

22 ANR.DJS, Liga Culturală, file 8/1926, 188, 190-191.

23 Ostland, 1 (1926), p. 399; 2 (1927): 256.

24 ANR.DJS, Liga Culturală, file 5/1925, 351-354.

25 Ibid., file 8, 1926, 451-452.
} 
the monthly magazine Ostland edited by CLRG between 1926 and 1931. The subtitle of the journal succinctly expresses its programme: "From the spiritual life of the Germans living abroad" (Vom geistigen Leben der Auslanddeutschen). In a letter to Rudolf Brandsch, the chairman of the German Union in Romania, Csaki called the magazine "a spokesman of the special endeavours of the Cultural League" 26 for upholding and affirming the cultural identity of the eastern Germans, of all the German minorities. The editorial board of the magazine has informed about the publication preparations for the new periodical and has requested the support and cooperation of personalities from among the German minorities in the East, the Balts included (R. v. Engelhardt, E. Ammende and so forth). ${ }^{27}$

The magazine has set up the aim of being a mirror of the cultural and national activity of the German communities in Eastern Europe. As far as the Baltic Germans are concerned, this aim was achieved to a large extent at least in the first years from its publication. In the pages of the magazine articles about the life ${ }^{28}$ and history ${ }^{29}$ of the national communities of Latvia, Estonia and Lithuania have been published. On the request of the editorial board, Axel de Vries has presented the national-cultural autonomy of the Estonian Germans as established according to the 1925 law and its achievements. ${ }^{30}$ This system of minority politics was followed with interest by other minorities who aspired to the status of cultural autonomy. The description of specific elements has approached the foreign influence on the language spoken by German Balts. ${ }^{31}$ Mention should be made here that a well known linguist from Transylvania, Andreas Scheiner (1864-1946) ${ }^{32}$ made a comparative study on the language spoken by native Baltic Germans and the Saxon dialects. His study was published in another journal from Sibiu, "Deutsche Politische Hefte aus Großrumänien", edited by Rudolf Brandsch33, where other contributions of several Baltic authors were also published. In this way, the question of Baltic minorities, the

\footnotetext{
26 Ibid., file 5, 1925, 655.

27 Ibid., 914, 918; file 7/1926, 132, 134.

28 Ostland, 2 (1927): 37-40, 109-113, 301-311.

29 Ostland, 4 (1929): 113-119, 322-332.

30 Ostland, 1 (1926): 59-63.

31 Ostland, 5 (1930): 202-207.

32 For details see Stefan Sienerth, 'Zur Bibliographie und zum Werk von Andreas Scheiner

(I)', Forschungen zur Volks- und Landeskunde, 31 (1988), 2: 65-77 and Stefan Sienerth, 'Zur

Bibliographie und zum Werk von Andreas Scheiner (II)', Forschungen zur Volks- und

Landeskunde 32 (1989), 1:65-77

33 Deutsche Politische Hefte aus Großrumänien, 7 (1927):154-163)
} 
agrarian situation in Estonia ${ }^{34}$, were presented to the Transylvanian readers. Articles about the Baltic Germans appeared also in the Saxon newspapers, but the greatest contribution to the knowledge of the realities of the German Baltic society must be attributed to Ostland review. In this magazine were also published several literary works of German Baltic authors like Otto von Schilling, Arthur Kerkovius (poets), Albert Kivikas, Irene von Styrk, Monika Hunnius (prose writer) ${ }^{35}$. The editorial secretary of the magazine, Konrad Nussbacher, argued in a letter from February 1926, addressed to the Riga prose writer Werner Bergengruener (1892-1964), that the mutual knowledge of literature of the German groups from abroad was one of the most appropriate ways for their intimacy and Ostland had made that its main goal ${ }^{36}$. But the magazine would not publish any kind of literature. Nussbacher exercised his abilities of literary critic on several poems send by a professor from Tartu. ${ }^{37}$

The writer Mia Munier-Wroblewska (1882-1965) had a more close connection with the Saxons in the 1920s. During a visit, in 1927, she participated to the May Day festival of the Sibiu Saxons and was highly impressed by the festivities in the city and from Dumbrava Sibiului. She published her impressions in Rigasche Rundschau and from there they were collected by the Siebenburgish- Deutsches Tageblatt daily newspaper"38. In the same year, Adolf Schullerus, Locum bishop, ethnographer and president of the Saxon National Council, wrote a eulogistic review of a novel by Mia Munier-Wroblewska, inspired from the life of Baltic Germans. The author underlined that, although the Baltic Germans were a people of counts and barons yielding to the Tzar, they were brought to fight in 1914, against their German brothers from the Reich. Scullerus found in the novel of the Baltic writer a new perspective upon the Germans from the foreign countries ${ }^{39}$. The writer from Latvia had been in Transylvania on several occasions and she was inspired by a local legend about the building of the Evangelic church from the town of Sebes. In 1932, a short novel was published in Germany with the title Der Bauermeister $z u$ Muhlbach (The Sebes Architect), which had a great success to the public, as the number of the published copies exceeded ten thousands.

\footnotetext{
34 Deutsche Politische Hefte aus Großrumänien, 2(1922), no.3: 17-20, no. 10: 7-11

35 Ostland, 2 (1927), 7-8; Ostland, 3 (1928): 12-14,325-328, 343

36 ANR DJS, Liga Culturala, file 10/1926, 628

37 Ibid., 868-869

38 Siebenburgisch-Deutsches Tageblatt, 54, no. 16.175 (7.08.1927): 3

39 Siebenburgisch-Deutsches Tageblatt, no. 16252 (2.09.1927): 2-3
} 
The pages of Ostland offer a clear image of the German Baltics' education system, beginning with its history (German schools attested already from the 13th century) and up to the situation of the German schools from Estonia, which enjoyed autonomy in the cultural administration, but they were facing great difficulties in collecting the necessary money after the agrarian reform had destroyed their basis of support through the expropriation. Here the situation was similar to that of the Saxon educational system. Like the Saxons, the Baltic Germans proved their self-denial and discipline capabilities in order to maintain their schools. On the occasion of the 125th anniversary of the German University in Tartu/Dorpat, Johannes Beermann recreated, for the readers of Ostland, the history of this institution, where 14,000 young people had studied up to its transformation into an Estonian institution, after the war. ${ }^{40}$

In March 1926, The Union of the German Teachers from the Baltic Countries invited the CLRG and the associations of the teaching board from Transylvania at its seventh annual reunion, thus trying to establish professional connections. ${ }^{41}$

The readers of the magazine also found out about the role played by the evangelical priests in the spiritual life of the Saxon community and of the German Balts. The occasion for this comparison was brought by the centenary of August Bienensteins, the founder of the Latvian linguistics and ethnography. 42

The editorial board of the magazine was on the Germans from Estonia's side also on Emil Fahle's death (1875-1929), the general director of the Factory of Cellulose and Paper from Tallin, a remarkable personality who granted a great financial support to the culture and the church of the German Balts ${ }^{43}$.

An issue that the journal approached starting with the presentation of the Yearbook of the Baltic Germans from 1928, was that of their presence in Germany. R. Csaki highly appreciated the fact that the Balts' associations from the Reich were preoccupied with the preservation of their conscience and of their identity. He wrote that the way in which they solved this problem and their contacts with their mother country was exemplary for all other German minorities. This preservation of self-conscience and identity Csaki considered as useful to "the German idea" 44 .

\footnotetext{
40 Ostland, 3 (1928): 59-60

41 ANR DJS, Liga Culturala, file 10/1926, 1210; file 158/1927, 14-15

42 Ostland, 1(1926): 174

43 Ostland, 4, (1929): 272-273

44 Ostland, 3, (1928): 63
} 
The preoccupation of the Ostland magazine for the German Balts was greater than for any other groups of Germans living abroad, who were more numerous, and made possible that this publication be well regarded in the intellectual circles from the Baltic states. The magazine was requested for exchange by local German periodicals but it had few subscribers. In 1926, Max von Ravick welcomed the magazine as an "organ who was gathering all the Germans from the East" and promised to make lobby for it and to become a collaborator. But, he argued, "for our situation, the high price allows only few persons to become subscribers. The German magazines, which before the war were not missing from any intellectual's house, today can be subscribed only by certain associations and libraries" 45 .

Ostland was received with great interest also by the publications of the Baltic Germans. Thus, Rigasche Rundschau appreciated the magazine from Sibiu because all its articles "resonated the national conscience and spiritual finesse", wished it good luck and "a long echo from Brasov and Levoca to Riga and Tallinn". 46

Moreover, the Ostland magazine also followed with great attention the German Baltic press. It was presented by Konrad Nussbacher in the special issue dedicated to the German press from abroad. He argued that Revaler Bote (chief editor A. de Vries) and Rigasche Rundschau (led by dr. Paul Schiemann) were above the level of the provincial newspapers and were "true examples for the way the German newspapers from abroad fulfilled their missions" 47 . In 1929, Revaler Bote daily newspaper with 30.000 copies, was gratified on the occasion of its 10th anniversary. The newspaper was considered a success of the Estonian Germans, who were appreciated as "the bravest minority of the German people" 48 . The daily newspaper had a few readers also among the Saxons. ${ }^{4}{ }^{9}$

In 1928, the editorial board of Ostland magazine gladly welcomed the issuing of a new magazine in Tallinn, Baltische Geistesleben. Zeugnisse aus deutscher Kulturarbeit (The Baltic spiritual life. Testimonies of the German cultural work), which had among its collaborators some of the most remarkable intellectuals from Estonia and Latvia (R. v. Engelhardt, H. Oncken, Alex Keyserling). In the same year, after a gap of twelve years, in Riga was published Baltische Monatsschrift (The Baltic monthly review) edited by Waldemar Mulsius, Werner Hasselblatt and Max Boehm. Ostland

\footnotetext{
45 ANR, DJS, Liga culturala, file 9/1926, 378

46 Apud R. Csaki, Tatigkeitsbericht 1922-1927, Hermannstadt, 1927, 26

47 Ostland, 1 (1926): 219

48 Ostland, 4 (1929): 339

49 ANR.DJS, Liga culturala, file 10/1926, 1002
} 
wished that both periodicals would become distinctive voices in the choir of the "spiritual life of the Germans from Eastern Europe"50 and maintained a regular exchange with them ${ }^{51}$.

The publication of the Ostland magazine, its distribution in the Baltic states and the finding of German collaborators from this area, allowed close relations between the editorial boards and several local German personalities.

From the recorded correspondence one finds out that the efforts of the Sibiu Saxons were highly appreciated in Riga, Tallinn, Tartu and the other centres inhabited by Germans, where the magazine was known and read. Sometimes, the editorial board received, besides support and advices, proposals for the improvement of its content. ${ }^{52}$ On the other hand, due to this interest, from the Baltic Germans' experiences, the editors were permanently trying to present as many aspects as possible from the life of their co-nationals from the Baltic Sea rim (cultural autonomy, artistic life, educational system, press, social life).

The publications of the Baltic Germans numbered among the 250 newspapers and magazines the press office of CLRG received in exchange for Ostland and the bulletin Pressenachrichten, it edited. In the office the main news and information were processed, the data being introduced in a card index which offered an ample image of the political, economic and cultural situation from the entire Eastern Europe. ${ }^{53}$ In this sense, Csaki was searching for connections also with Oriental Prussia and Lithuania in 1926.54

The exchange of books between different German cultural societies and associations from the Baltic states took place and was equally intense. The Cultural League was sending especially papers published by its own publishing house: Was jeder Deutsche von Siebenbürgen und den Siebenbürger Sachsen wissen muß, Aus den siebenbürgisch-sächsischen Volksdichtung, the yearbooks of the Germans from Romania.

The experience of CLRG in the field of the popular libraries was also known in Lithuania (Jurburg Department), where Martin Labrenz asked for support in order to found a local library, which would had been the first German library from Lithuania, at the service of the national activity of the Germans from this country. Csaki sent them magazines, books and

\footnotetext{
50 Ostland, 3 (1928): 131, 156

51 ANR.DJS, Liga culturala, file 14/1928, 164-165

52 ANR.DJS, Liga culturala, file 10/1926, 117-118, 507-518, 866-867

53 R. Csaki, 27, 28; ANR.DJS, Liga culturala, file 5/1925, 350, 352; file 6/1925, A-K, M-Z

${ }^{54}$ ANR.DJS, Fond Culturala, file 9/1926, 19
} 
technical expertise and promised to counsel other associations to donate books to the new library55.

In other area of interest of counsel, the theatre, Konrad Nussbacher noticed that the Transylvanian Germans had to learn from the experience of their Baltic states compatriots regarding the organization, the financial support and superior education of the public. ${ }^{56}$

The conferences organized by CLRG served to the reciprocal acquaintance of the Germans from the two regions. Thus, in 1925, in Transylvania, dr. P.G. Luig and Mia Munier-Wroblewska spoke about "The Problems of the Germans from the Baltic states", focusing on a small Baltic town. ${ }^{57}$ In the fall of 1924, CLRG tried to send a Saxon choir in Latvia and Estonia but the attempt failed as several artistic tours from Germany and Austria were already going there 58 .

The CLRG struggled to mediate also business relations between the Baltic states and Transylvania, although the results were very modest. Thus, in 1924, Samuel Karres, a leather manufacturer from Medias, asked for the support of the Cultural League, in order to create a market for his products in the Baltic states ${ }^{59}$.

The visits of small groups of Baltic Germans made in 1923, 1926 and 1928 , played a major role in the establishment of the economical relations ${ }^{60}$. This fact was signalled also by Max Ravick in a letter to Csaki: "Through your visit here and our citizens' trip to your country, the interest for Transylvania rose very much" 61 . During these visits to the Baltic states, the associations of the German cooperatives from Transylvania and the Baltic states exchanged their experience; the Balts were especially interested in the organization of the Land Credit Institute of Sibiu as a cooperative ${ }^{62}$, a real bank, with a special contribution in supporting the Baltic agriculture. Csaki was also received warmly in the Baltic states in 1923 and 1928. As he later confessed to a friend, nowhere did he receive such a warm reception as in Riga, where he wanted to return. ${ }^{63}$

Moreover, Csaki was very appreciated among the Baltic Germans for his knowledge in the field of the politics of culture. In December 1925, Ewald

\footnotetext{
55 Ibid., file 8/1926, 445-451

56 Ostland, 1 (1926): 83-88

57 ANR.DJS, Liga culturala, file 6/1925, 242, 886, R. Csaki, 1927, 22

58 ANR.DJS, Liga culturala, file 4/1924, 446, 456

59 Ibid. 51-52

60 Ibid., file 9/1926, 887; file 10/1926, 437

61 Ibid., file 9/1926, 379

62 Ibid.,file 4/1924, 692,921

63 Ibid., f. 1175
} 
Ammende asked from Pärnu for his advice in regard to Estonians' administrative organization in the cultural field. This aspect was of particular importance for all national minorities interested in the question of cultural autonomy. In a paper on the question of the cultural organization of the German minorities, presented in July 1925 in Vienna, Csaki appreciated that Estonia ranked first in the world in regard to minorities' right of cultural self-administration. ${ }^{64}$ Csaki's advice was also asked because of his good relations with important political figures in Germany. ${ }^{65}$

The relations between the Baltic Germans and the Saxons were very complex. Although I will not discuss them in detail with this occasion, there is another aspect that deserves to be mentioned, namely the contacts among students. CLRG mediated the contact between The Union of German Students from Riga and The League of German Students from Romania. The later edited also a magazine, Akademische Blätter that was regularly sent to Riga.66 In 1926 a plan for a student exchange between students from Transylvania and their counterparts from Baltic States was elaborated.67 The students of the two regions interacted with each other also in the framework offered by The Central Union of German Students from Abroad, which functioned in Germany. This Union numbered, in 1927, 317 members from Romania, 135 from Latvia, seventy two from Estonia and ten from Lithuania. In the meetings of this organization, problems concerning the country of origin were sometimes discussed, and that contributed to a better mutual understanding. ${ }^{68}$

The leaders of the Balts and Saxons have always considered and emphasized the historical similarities between the two ethnic groups: both descendent of the oldest German colonies, one from the Baltic Sea, the other from the Black Sea and Carpathians. In January 1926, Csaki asked Max Hildebert Boehm, one of the leaders of the Germans living abroad, to write an article for Ostland, focused on a comparison between the situation of the Germans from the Baltic States and those from Romania. Boehm will publish the article only in 1945.69 In February 1926, Csaki addressed a similar request to the philosopher and writer Hermann Keyserling (1880-

\footnotetext{
64 Ibid., file 108/1924-1925, 134

65 Ibid., file 2/1923, 1692-1693.

66 Ibid., file 3/1924, 42.

67 Ibid., file. 7/1926, 210, 213.

68 Ostland, 2 (1927): 295; Ostland, 3 (1928): 22-23.

69 ANR.DJS, Liga Culturală, file10/1926, 862, 866-867.
} 
1946), native from Livonia. ${ }^{70}$ It was also in 1926, when Dr. K. Stavenhagen, from the Office of Baltic Germans from Riga, reading an article by the Saxon journalist Emil Neugeboren, about the 'Transylvanian soul', concluded that geographical landscape and coexistence of the same ethnicities within the same space lead to the appearance of a 'community of soul' and therefore he claimed that it also existed a 'Baltic soul' as a result of the coexistence of Baltic Germans and Latvians. ${ }^{71}$

In the same sense, Csaki asked different personalities of the Weimar Republic, who had visited both Transylvania and the Baltic states, to compare the two peoples on the basis of their travel notes. ${ }^{72}$ Despite his efforts, Csaki never received the study he wanted on this theme. In the same year, 1926, in Dresden, he promised to an editor of a youth magazine to send an article focused on the comparative study of the Baltic and Transylvanian Germans. ${ }^{73}$ Becoming a real organizer of the cultural activities of the German minority in Romania and one of the most informed people on the issue of the German minority in Europe in general, Csaki kept his promise and send the article during the next year, in 1927.74

The relations between the Baltic and Transylvanian Germans represent just one aspect of the intensive campaign started in 1919 and designed to rebuild Germany's prestige and greatness. During the first inter-war decade, the German minorities from Europe had to face the nationalism of the governments of the new European states. By developing the relations and networks among the German communities, the leaders of the minority sought to keep and strengthen their national identity. Later, these communities were to be used by the leaders in Berlin to impose their political will and influence abroad. Although, during the 1920s the German leaders acted prudently, in the 1930s, the German minorities had been completely subordinated to the political will of the German government.

The close relations between the Baltic and Transylvanian Germans represent a less known aspect of the relations between Romania and the Baltic states during the inter-war period in general. However, recent well documented studies have shed some light on these issues. 75

\footnotetext{
70 ANR.DJS, Liga Culturală, file10/1926, 745.

71 Ibid., 510.

72 Ibid., 728.

73 Ibid., 48.

74 Richard Csaki, 'Balten und Siebenbürgen Sachsen', Roland-Blätter, I (1927), nr. 2: 3-4.

75 Florin Anghel, ' O încercare românească de politică baltică. România şi Letonia în perioada interbelică', Național şi universal în istoria românilor. Studii oferite prof. Dr. Şerban Popacostea cu ocazia împlinirii a 70 de ani (Bucureşti, 1998) 435-450; Silviu Miloiu, România şi Țările Baltice în perioada interbelică, Târgovişte: Cetatea de Scaun, 2003).
} 